\title{
The Effect of Discipline and Learning Ways on English Achievement through Learning Motivation as a Moderator Variable
}

\section{Giga Cipta Novelia}

\author{
Novelia.cipta@gmail.com
}

\begin{abstract}
This research was carried out to describe and analysis; (1) whether there is simultaneously positive significant effect of discipline and learning ways on English achievement at the second grade students of SMAN 1 Grogol is or not, (2) whether there is partial positive significant effect of discipline on English achievement at the second grade students of SMAN 1 Grogol is or not, (3) whether there is partial positive significant effect of learning ways on English achievement at the second grade students of SMAN 1 Grogol is or not, (4) whether there is positive significant effect of discipline and learning ways on English achievement through learning motivation as a variable moderator or not. The research used descriptive quantitative approach as the research design. The data analysis method was regression while the techniques of collecting data were survey by giving questionnaire and from student report value. In this research, the population consists of 104 students of second grade. The result showed that: discipline, learning ways and learning motivation have simultaneous and partial positive significant effect on English achievement.
\end{abstract}

Key words: Discipline, Learning Ways, English Achievement, Learning Motivation.

\section{Introduction}

English is an international language, which if the students want to plunge into the wider world then, students must learn English properly and correctly. At schools, English achievement can be seen from the student report value of English. It is supported by the statement of Winkel (2004) that stated the value of achievement contains: 1) The final value of the average formative test with summative tests. 2) The final value of the average value of assignments, extracurricular activities followed daily test scores and general grades. According 
to Suryabrata (2006) achievement is the form of final formulation given by the teacher that relates to certain initial learning.

In general, there are two factors that influence English achievement, namely internal factors and external factors. Purwanto (2004) stated that factors that influence learning can be divided into two groups, namely: (1) Factors that exist in the organism itself, called individual factors; (2) Factors that exist outside the individual, called social factors. Included in the individual factors are the factors of maturity/growth, intelligence, training, motivation and personal factors. The social factors include factors of family/household condition, teacher and ways of teaching, tools used in teaching and learning, environment and available opportunities, and social motivation.

Based on the opinion above, it can mean that discipline is included in one of the personal factors that can affect student English achievement. Siswanto (2001) considers that discipline is an attitude of respect, obedience to the applicable regulations, both written and unwritten and able to carry it out and not avoid accepting sanctions if they violate the duties and authority given to them. Flippo cited in Atmodiwirjo (2000) argues that discipline is every effort to coordinate one's behavior in the future by using law and rewards. The above definition focuses on understanding discipline as an attempt to organize one's behavior so that it is accustomed to carrying out something as it should be stimulated by punishment and reward. Atmosudirjo (cited in Atmodiwirjo (2000)) defines that discipline as a form of obedience and self-control closely related to rationalism, conscious, not emotional. This opinion illustrates that discipline is a 
form of compliance with rules through self-control which is carried out through rational consideration. Thus it can be concluded that discipline is a form of obedience so as not to get punishment.

Discipline in learning English that is good or can be said to be high can encourage students to achieve high English achievement. But in reality, the level of student English learning discipline in school between students is different due to the influence of different family environments and school environments. In an educational institution, English learning achievement is an important indicator for measuring student success. However, it cannot be denied that the high and low student English achievement is influenced by factors besides the teaching and learning process itself (Arikunto, 1990). Discipline contained in students becomes the main factor for good English learning achievement because some experts think that the best motivation is self-motivation, as well as discipline. But in reality, the internal factors alone are not enough to fully support the process of English learning achievement without the support of an English teacher as a mentor in the teaching and English learning process. Because most of the time that is owned by students in the school he interacts with the English teacher's tutor. This is where it needs to be optimized on how to follow up in improving performance through the implementation of strong learning motivation and good student English learning discipline. Besides, to improve student English achievement, the schools that become educational facilities need to provide complete and adequate learning facilities such as English laboratory and schools 
must be able to create discipline of students by carrying out school rules by all school residents.

Thus it can be said that English achievement is influenced by the discipline of learning English. The existence of these influences shows that the higher the English learning discipline of a student, the higher the English learning achievement obtained, on the contrary, the lower the discipline of learning English, the lower English learning achievement achieved. Based on the results of the research, it can be seen that the average level of student discipline is high, there are only a few who show less discipline.

Not only discipline that can affect student English achievement but how to learn English is also another factor that can influence, to get good results, good and right learning English methods are needed. The ways of learning English for each student is different, and each method of learning English has positive and negative values, as well as the impact on students themselves and around them. Students who do not know their English learning style will produce poor learning English achievement. Besides, of course, the quality of good education also influences students' English learning styles, as well as the student's environment. But the high motivation for students to develop English learning styles is very supportive to achieve English achievement.

Each student has different ways of learning English between one another in the physical aspects, thinking patterns, and how to respond or learn something new. Every student has different ways of learning English according to their thinking abilities. Hamalik (1983) argues about learning ways are activities 
carried out in learning something, meaning activities that should be carried out in certain learning situations. In certain situations, certain leaning ways are also needed. Learning ways that are used also determines the expected English learning outcomes. Slameto (1995) suggested that learning ways are learning habits or ways of learning that affect learning include, among others; repeat lesson material, read and take notes, concentrate, do assignments, how to manage learning time.

How to learn English can be seen from several aspects, namely: (1) How to make a schedule and implementation; (2) How to read a book; (3) How to make notes; (4) How to take lessons; (5) How to repeat the lesson; (6) How to concentrate; (7) How to memorize lessons; (8) How to take the exam.

Many argue that the secret of successful learning English lies in one's recognition of himself, the suitability of English teaching style and English learning style, its potential, and the consequences it causes. Students with low English achievement are students whose English learning styles do not match the English teacher's teaching style at school. Thus it can be said that the ways of learning English have to do with student English achievement. Because if want to get high English achievement, then must have effective ways of learning English and also if the ways to study English at home are not good, then English achievement is also less satisfying.

From the description above it can be concluded that discipline and also learning ways can affect English achievement itself. Having a high level of discipline in learning English will be different from someone who has a low level 
of discipline in learning English. Usually, people with less discipline in learning English are lazy people. With this lazy nature will make a decrease in productivity included in English achievement in school. Having a good and effective English learning method by following the comfort of students will make students more enthusiastic in learning English because they already know how to learn fun and can make them comfortable so that it will affect English achievement, it is different from students who are just careless in learning English because they have not found ways of learning English that makes them comfortable so that it will make students become lazy in learning English and will make English achievement decrease.

In this study, there is one variable moderator which is an indirect variable. In this study, there is learning motivation as a moderator variable. How learning does not directly affect English achievement is one of the connecting variables that is learning motivation. According to Uno (2011), learning motivation is internal and external encouragement to students who are learning to conduct behavior, in general with several indicators or supporting elements. These indicators include the desire and desire to succeed, encouragement and needs in learning, hopes and aspirations for the future, appreciation in learning, and a conducive learning environment. In this research, the researcher wants to examine the magnitude of the results obtained by using a moderator variable, will the greater results obtained or even fewer.

Based on observations made by the researcher while teaching English Club in SMA N 1 Grogol for approximately two years. There are some students 
who a high level of discipline, some are lacking, as well as student motivation. Students who have gone to the English course are quite good, but some students have never had an English achievement course that is not bad at English achievement. Therefore, from that explanation, the researcher will raise research related to student English achievement and what can affect student English achievement.

\section{Literature Review}

\section{Discipline}

Siswanto (2001) considers that discipline is an attitude of respect, and obedience to the applicable regulations, both written and unwritten and capable of carrying out them and do not avoid receiving sanctions if they violate the duties and authorities granted to her. Besides, according to Slameto (1997), there is a learning discipline at school with four types then Wijaya and Rusyan (1996) stated there is a discipline at home.

\section{Learning Ways}

Learning ways are study habits or ways of learning that affect learning include, among others; repeating lesson material, reading and taking notes, concentrating, doing assignments, how to manage learning time (Slameto, 1995). Then, learning ways according to The Liang Gie (1994) distinguish into four groups, each of which includes several certain kinds of skills.

\section{English Achievement}


Suryabrata (2006) suggests that are achievement which is the form of final formulation given by the teacher that relates to certain initial learning. Then, Winkel (2004) stated that the value of achievement contains: 1) The final value of the average formative test with summative tests. 2) The final value of the average value of assignments, extracurricular activities followed daily test scores and general grades.

\section{Learning Motivation}

According to Uno (2011), learning motivation is internal and external encouragement to students who are learning to conduct behavior, in general with several indicators or supporting elements. Besides, Winkel (2005), mentions learning motivation is the overall psychic driving force in students that causes learning activities to achieve a goal.

\section{Method}

The design of the research used is a quantitative approach. According to Heryadi (2008), quantitative comes from the results of philosophers who prioritize scientific thinking. This can be seen by looking for the truth about a problem or phenomenon that must start from the existing truth, namely principles, axioms, arguments, and certain theories. Heryadi (2008) also explains that the language research methods which are excessively used are descriptive, experiment, and classroom action research methods. Finally, the research method data analysis used is regression analysis and the technique used is surveyed by using a questionnaire and student report value. 


\section{Population and sample}

This research done at March, $6^{\text {th }}$ 2019. SMAN 1 Grogol Kediri as a place of research and the subject were the second grade which has several majors and it locates at Jl. Raya Gringging 16 Sonorejo, Kec. Grogol, Kab. Kediri 64151, East Java.

Table 1: $\quad$ Population of The Research

\begin{tabular}{|l|l|c|c|}
\hline No. & Majors & Total Class & Total Student \\
\hline 1 & IPA & $5 \times 36$ & 180 \\
\hline 2 & IPS & $4 \times 36$ & 144 \\
\hline 3 & BAHASA & $1 \times 36$ & 36 \\
\hline \multicolumn{2}{|c|}{ Total } & 360 \\
\hline
\end{tabular}

The sample used in this study is the Sloven form. The researcher took a sample of 5 classes with totaling 180 respondents that classes are MIA 2, MIA 3, MIA 4, IIS 3 and IIS 4 because the rule of school only can give that class to be researched. However, because of the conditions at which data were collected were not conducive, many students who did not enter the class and also the lessons were ineffective caused only 142 data from the respondent to be obtained. So, the sample must be calculated again using the Sloven formula and got 104 students as a sample. So, the researcher took 20 samples each per class (MIA 2, MIA 3, MIA 4, IIS 3 and IIS 4 took the sample by using absence sequence) in which the total number of samples was 104 students. 


\section{Research instruments}

The research instrument is a research tool to make it easier for researchers to collect data and get good results. This research used the questionnaire and student report value. In preparing the instrument, the researcher follows the steps, namely, describing the variables into aspects, describing aspects into indicators, then making an instrument grid and describing the indicators into statements. In its development later, this instrument is made closed using a Likert scale. This Likert scale assesses the behavior desired by researchers by submitting statements to respondents. Then the respondent was asked to respond to the answer with the measuring scale provided.

This questionnaire also used negative statements to control the accuracy and seriousness of the respondents in filling out the questionnaire so that the scores given were reversed with those mentioned above. There are three questionnaires, the first questionnaire related to discipline contained 10 numbers. The second questionnaire related to learning ways contained 12 numbers. The third questionnaire related to learning motivation contained 10 numbers.

\section{Validity of research instruments}

An instrument is said to be valid if the instrument can be used to measure what should be measured (Sugiyono, 2011). The correlation used is the Product Moment Correlation from Pearson. From the results of the validity test by using SPSS 25, the three outputs from the first are X1 (Discipline), the second variable is $\mathrm{X} 2$ (Learning Ways), the third variable is $\mathrm{X} 3$ (Learning Motivation). From the output, it can be seen the correlation value between each 
item with the total item score. All data are declared valid because there is a correlation with a significance of $1 \%$ and $5 \%$, or bias can be seen easily with a one-star sign for a significance of 0,01 and two stars for a significance of 0,05 . So it can be concluded that all data contained in all variables are all valid.

\section{Reliability of research instruments}

A reliable instrument is an instrument that can be used several times to measure the same object and produce the same data. Criteria for determining instrument reliability, if the alpha value is greater than 0,60 then the instrument is reliable, and vice versa if it is smaller than 0,60 then the instrument is not reliable.

The measurement of the reliability of the self-concept variable obtained by the alpha coefficient of 0,833 and the reliability of the disciplinary variable based on the score of the violation obtained an alpha coefficient of 0,669. From the results of the reliability test, we get three outputs, namely variables $\mathrm{X} 1, \mathrm{X} 2, \mathrm{X} 3$ and $\mathrm{Y}$. From this output, we can find out the reliability value (Cronbach's Alpha) for each variable. For the X1 (Discipline) variable Cronbach's Alpha value is 0,613, for the X2 (Learning Ways) variable Cronbach's Alpha value is 0,662 , for the X3 (Learning Motivation) variable Cronbach's Alpha value is 0,730 . From these results, it can be concluded that only all variable is reliable because the Cronbach's Alpha value is > 0,6.

\section{Normality test}

Normality testing in this study used the Kolmogorov-Smirnov test in IBS SPSS Statistics 25. The requirements for the variable data are normally 
distributed if the value of Sig. Kolmogorov-Smirnov greater than 0,05. By using IBM SPSS Statistics 25 program, the value of Asymp. Sig. (2-tailed) worth 0,200 and the Test Statistic is 0,060 . This value is higher than 0,05 $(0,200>0,05)$. This shows that the data is normally distributed.

\section{Linearity test}

Linearity test is used to find out is there a linear relationship between the independent variable and the dependent variable. Variables are said to be linear if the value of deviation from linearity is $>0,05$. Linearity tests are calculated using the help of the IBM SPSS Statistics 25 program. The results showed that: (1) The linearity test results between disciplines of English achievement, the significance value of linearity is 0,021 and the result of Deviation from Linearity obtained is 0,305 that means the discipline variable for English achievement is linear. (2) The results of the linearity test between learning ways variables on English achievement, that the significance value of linearity is 0,013 and the result of Deviation from Linearity obtained is 0,514 that means learning ways variable for English achievement is linear. (3) The results of the linearity test between discipline variables on learning motivation, the significance value of linearity is 0,061 and the result of Deviation from Linearity obtained is 0,193 that means discipline variable for learning motivation is linear. (4) The results of the linearity test between learning ways variables on learning motivation, the significance value of linearity is 0,018 and the result of Deviation from Linearity obtained is 0,885 that means learning ways variable for learning motivation is linear. (5) The results of the 
linearity test between learning motivation variables on English achievement, the significance value of linearity is 0,083 and the result of Deviation from Linearity obtained is 0,193 that means learning motivation variable for English achievement is linear.

\section{Multicollinearity test}

The multicollinearity test is calculated using the IBM SPSS Statistics 25 program by means of a regression test. The multicollinearity test results for discipline variables (X1), learning way variables (X2) and learning motivation variable (X3) have a Statistics VIF value 1,370 for X1 variable, Statistic VIF value 1,442 for X2 variable and Statistics VIF value 1,063 for X3 variable. Then, the collinearity tolerance value of $\mathrm{X} 1$ variable is 0,730 , the collinearity tolerance value of X2 variable is 0,693 , and the collinearity tolerance value of $\mathrm{X} 3$ variable is 0,941 . The test results value show that the Statistics VIF value is less than 10 and Collinearity Tolerance more than 0,1 for all three variables, thus it can be concluded that in the regression between the independent variable discipline (X1), learning way variable (X2) through learning motivation (X3) on English achievement (Y) there is no multicollinearity problem.

\section{Heteroscedasticity test}

Heteroscedasticity is a condition in which there is a variance in residual variance for all observations in the regression model. One of the Heteroscedasticity test method is Glejser test. Gletser test is done by regressing independent variable to absolute residual values. By using SPSS Program vs. 
25 the results showed that significance value for discipline is 0,057 , for learning ways is 0,316 and for learning motivation is 0,783 . Because of the significance is more than 0,05 , so that can be concluded that in the regression model there is no heteroscedasticity problem.

\section{Data collection technique}

This research used a questionnaire as a data collecting method and student report value. Questionnaires which researcher use because to found out the research questions. The first method by using a questionnaire could facilitate the respondent to give an answer that matched the student's choice or an alternative answer was available in it and requires a relatively short time to answer it. The second method by using a document of student report value.

\section{Data analysis technique}

The data analysis technique used in this research is descriptive analysis and regression. The description of the data carried out includes the size of the concentration and distribution of data. The size of the concentration of data includes median, mode and median values. While the size of the data distribution includes variance and standard deviation. The data description is done by categorizing the scores of each variable. The score is then divided into four categories. Categorization is done based on the ideal Mean (Mi) and ideal Standard Deviation (Sdi) obtained (Mardapi, 2008). 


\section{Results and Discussions}

The following explained the results of the study of the influence of discipline and learning ways on English achievements through learning motivation of class XI students of SMAN 1 Grogol.

\section{The effect of discipline and learning ways on English achievement}

From the model summary of the regression' table, the value of $\mathrm{R}$ square is 0,808 its means that the simultaneous effect of discipline and learning ways have contributed $80,8 \%$ to English achievement, while the rest is influenced by other variables that not examined in this study.

Table 2: Coefficients table of discipline and learning ways on English achievement

\begin{tabular}{|c|c|c|c|c|c|c|}
\hline \multicolumn{7}{|c|}{ Coefficients $^{a}$} \\
\hline \multirow[b]{2}{*}{ Model } & & \multicolumn{2}{|c|}{ Unstandardized Coefficients } & \multirow{2}{*}{$\begin{array}{c}\text { Standardized } \\
\text { Coefficients } \\
\text { Beta }\end{array}$} & \multirow[b]{2}{*}{$\mathrm{t}$} & \multirow[b]{2}{*}{ Sig. } \\
\hline & & B & Std. Error & & & \\
\hline \multirow[t]{3}{*}{1} & (Constant) & 2,365 & 1,991 & & 1,187 &, 238 \\
\hline & Discipline & 904 & ,053 & ,870 & 17,044 & .000 \\
\hline & Learning Ways & .046 &, 044 &, 054 & 1,050 & 296 \\
\hline
\end{tabular}

Based on the regression results, the magnitude of the constants (a) $=$ 2,365 and the regression coefficient $(b)=0,904$, the regression coefficient $(\mathrm{c})=$ $0,046, \mathrm{~F}$ count $=211,973$ and $\mathrm{F}$ table $=3,090$. Because $\mathrm{F}$ count $>\mathrm{F}$ table $(211,973>3,090)$, then Ho is rejected. This means that Discipline and Learning Ways simultaneously influence English Achievement. 


\section{2.}

\section{The effect of discipline on English achievement}

From the model summary of the regression' table, the value of $\mathrm{R}$ square is 0,805 its mean that discipline has contributed $80,5 \%$ to English achievement, while the rest is influenced by other variables that not examined in this study.

Table 3: Coefficients table of discipline on English achievement

\section{Coefficients $^{\mathrm{a}}$}

\begin{tabular}{|c|c|c|c|c|c|}
\hline & & $\begin{array}{l}\text { standardized } \\
\text { cients }\end{array}$ & $\begin{array}{l}\text { Standardized } \\
\text { Coefficients }\end{array}$ & & \\
\hline Model & B & Std. Error & Beta & $\mathrm{t}$ & Sig. \\
\hline (Constant) & 3,098 & 1,866 & & 1,660 & $\begin{array}{r}, \\
100\end{array}$ \\
\hline Discipline & ,933 &, 045 & ,897 & 20,553 & $\begin{array}{l}\text { ' } \\
000\end{array}$ \\
\hline
\end{tabular}

a. Dependent Variable: English Achievement

Based on the regression results, the magnitude of the

constants $(\mathrm{a})=3,098$, the regression coefficient $(\mathrm{b})=0,933$, t count $=20,553$, and $\mathrm{t}$ table $=1,983$. Because the value of $\mathrm{t}$ count $>\mathrm{t}$ table $(20,533>1,983)$, Ho is rejected. This means that the discipline partially influences English Achievement. The value of $t$ count is positive, meaning that the influence that occurs is positive, or it can be interpreted as higher or better discipline of students, hence increasing student English achievement. 


\section{3.}

\section{The effect of learning ways on English achievement}

From the model summary of the regression' table, the value of $\mathrm{R}$ square is 0,254 its mean that learning ways have contributed $25,4 \%$ to English achievement, while the rest is influenced by other variables that not examined in this study.

Table 4: Coefficients table of learning ways on English achievement

\section{Coefficients $^{\mathrm{a}}$}

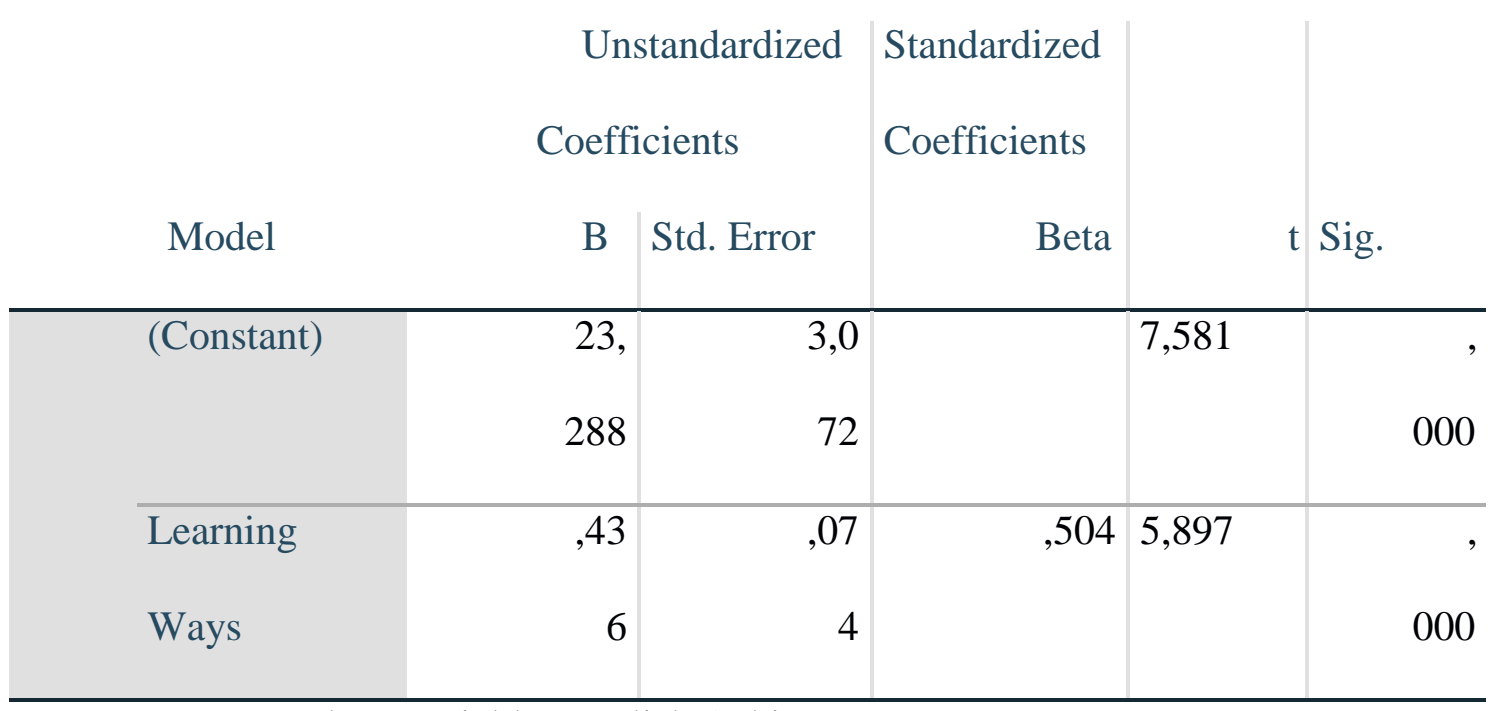

a. Dependent Variable: English Achievement

Based on the regression results, the magnitude of the constants $(\mathrm{a})=23,288$, the regression coefficient $(\mathrm{b})=0,436, \mathrm{t}$ count $=5,897$ and $\mathrm{t}$ table $=1,983$. Because the value of $\mathrm{t}$ count $>\mathrm{t}$ table $(5,897>1,983)$, then Ho is rejected. This means that learning ways partially influences English achievement. The value of $t$ count is positive, meaning that the influence that occurs is positive, or it can be interpreted as higher or better learning ways of students, hence increasing student English achievement. 
4. The effect of discipline and learning ways on English achievement through learning motivation as a moderator variable

From the model summary of the regression' table, the value of $\mathrm{R}$ square is 0,823 its mean that discipline and learning ways through learning motivation have contributed $82,3 \%$ to English achievement, while the rest is influenced by other variables that not examined in this study. After that, do regression test of $\mathrm{X} 1$ and $\mathrm{X} 2$ on $\mathrm{X} 3$. The results can be seen below:

From the regression result show that the significance value is 0,004 and 0,000 . With $\mathrm{R}$ square value is 0,865 . Meanwhile the value of e1 is obtained from:

$$
\begin{aligned}
& e 1=\sqrt{ } 1-R^{2} \\
& =0,502
\end{aligned}
$$

Thus obtained the path diagram of the structural model I as follow:

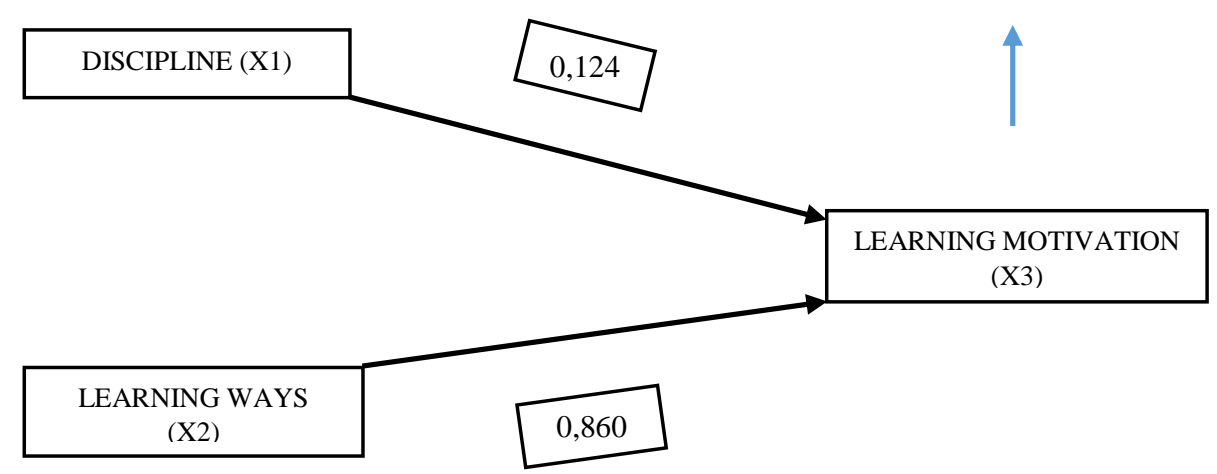

The following result is from regression test of the effect of discipline and learning ways on English achievement through learning motivation as a moderator variable, by using SPSS Program vs. 25: 
From the model summary of regression' table the value of R square is 0,823 its mean that discipline and learning ways through learning motivation have contributed $82,3 \%$ to English achievement, while the rest is influenced by other variables that not examined in this study.

From the regression results show that the significance value is 0,000 for $\mathrm{X} 1,0,035$ for $\mathrm{X} 2$, and 0,004 for $\mathrm{X} 3$. With $\mathrm{R}$ square value is 0,823 . Meanwhile the value of e1 is obtained from:

$$
\begin{aligned}
& e 2=\sqrt{ } 1-R^{2} \\
& =0,568
\end{aligned}
$$

By the result above, this following frame work result of the effect of discipline and learning ways on $\frac{1 \cdot}{0,502}$ achievement through lear $\dot{0,568}$ motivation as a variable moderator:

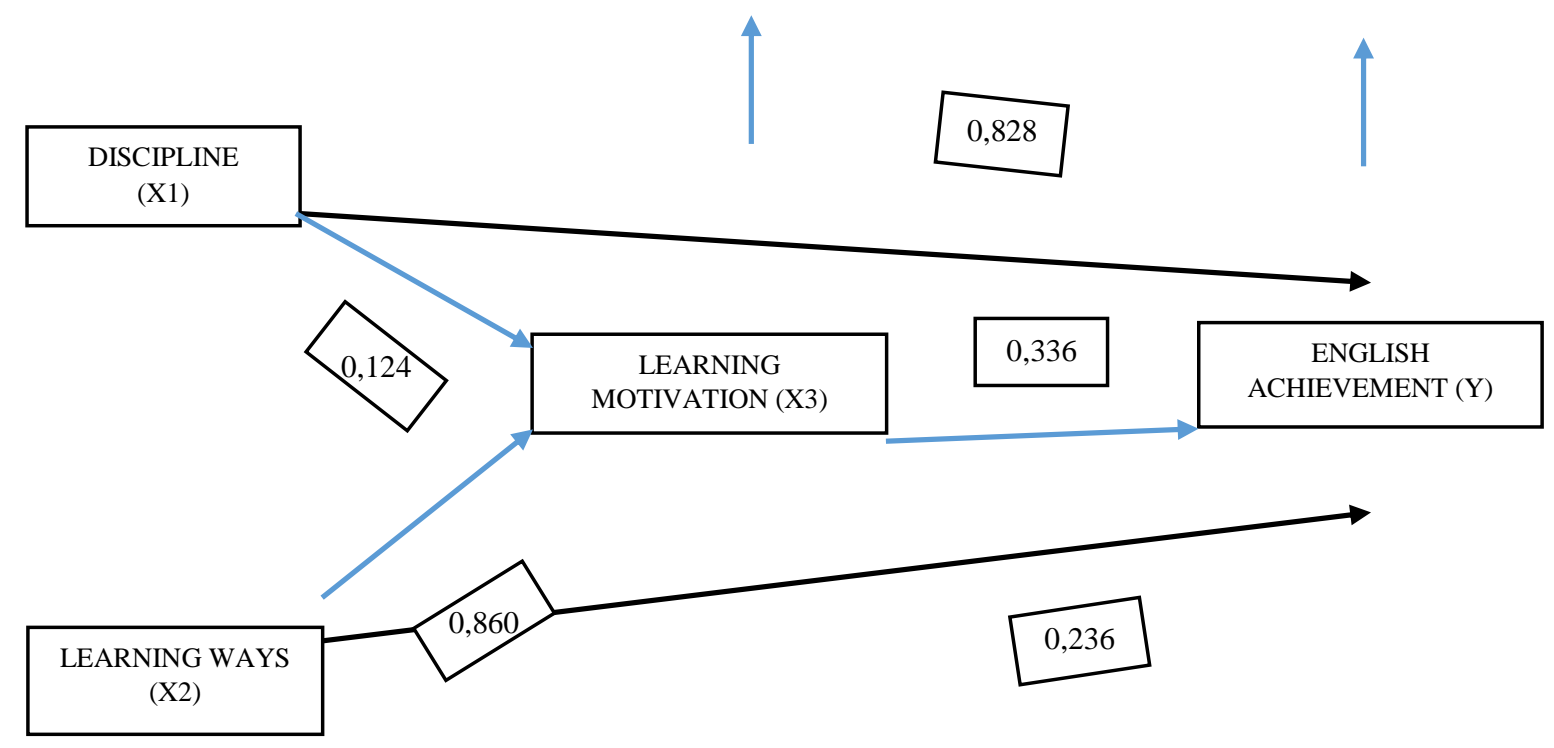


Analysis of the effects of $\mathrm{X} 1$ through $\mathrm{X} 3$ on $\mathrm{Y}$ : it is known that the direct effect of $\mathrm{X} 1$ on $\mathrm{Y}$ is 0,828 . While the indirect effect of $\mathrm{X} 1$ through $\mathrm{X} 3$ on $\mathrm{Y}$ is the multiplication between the beta value of $\mathrm{X} 1$ against $\mathrm{X} 3$ with the beta value of $\mathrm{X} 3$ against $\mathrm{Y}$, namely: $0,124 \times 0,336=0,042$. Then the total effect given $\mathrm{X} 1$ on $\mathrm{Y}$ is a direct effect plus the indirect effect namely: $0,828+$ $0,042=0,866$. Based on the above calculation results obtained the value of direct effect is 0,828 and the indirect effect of 0,042 which means that the value of the indirect effect is smaller than the value of the direct effect, these results indicate that indirectly $\mathrm{X} 1$ through $\mathrm{X} 3$ has no significant effect on $\mathrm{Y}$ and indirect result is not effective.

Analysis of the effects of $\mathrm{X} 2$ through $\mathrm{X} 3$ on $\mathrm{Y}$ : it is known that the direct effect of $\mathrm{X} 2$ on $\mathrm{Y}$ is 0,236 . While the indirect effect of $\mathrm{X} 2$ through $\mathrm{X} 3$ on $\mathrm{Y}$ is the multiplication between the beta value of $\mathrm{X} 2$ against $\mathrm{X} 3$ with the beta value of $\mathrm{X} 3$ against $\mathrm{Y}$, namely: $0,860 \times 0,336=0,289$. Then the total effect given $\mathrm{X} 2$ on $\mathrm{Y}$ is a direct effect plus the indirect effect namely: 0,236+ $0,289=0,525$. Based on the above calculation results obtained the value of direct effect is 0,236 and the indirect effect of 0,289 which means that the value of the direct effect is smaller than the value of the indirect effect, these results indicate that indirectly $\mathrm{X} 2$ through $\mathrm{X} 3$ has significant effect on $\mathrm{Y}$ and direct result is not effective.

From that discussion above it can be concluded "there is effect of discipline and learning ways on English achievement through learning motivation which has greater direct effect than indirect effect. The direct 
effect of discipline on English achievement through learning motivation is greater than the indirect effect because according to Winardi (2002), motives are the cause of action, thus it can be said that motivation should exist before discipline, because motivation can affect that things or the initial influence of all action. Winardi (2002) also believes that motives are the "why" of behavior. It arises and maintains activity, and determines the general direction of an individual's behavior.

\section{Conclusion}

From the research results and finding above it can be concluded that discipline and learning ways in have simultaneous positive significant effect on English achievement, discipline has partial positive significant effect on English achievement, learning ways have partial positive significant effect on English achievement, direct effect of discipline on English achievement through learning motivation has greater effect compared with indirect effect of discipline on English achievement through learning motivation and direct effect of learning ways on English achievement has smaller effect compared with indirect effect of learning ways on English achievement through learning motivation.

\section{About the Writer}

Giga Cipta Novelia graduated from the Faculty of Teacher Training and Education, Kadiri Islamic University. She is currently giving private lessons to 
high school students and helping them learn English. Her research interest is on language teaching, learning styles and learning motivation.

\section{References}

A.M, Sadirman. 2005. Interaksi dan Motivasi Belajar Mengajar. Jakarta: Rajawali Press.

Arikunto, Suharsimi. 1990. Dasar-dasar Evaluasi Pendidikan. Jakarta: Bumi Aksara.

Atmodiwirjo, Subagio. 2000. Manajemen Pendidikan Indonesia. Jakarta: PT Ardadizya Jaya.

Dalyono, Muhammad. 2007. Psikologi Pendidikan. Jakarta: Rineka Cipta.

Djalal, MF. 1986. Penilaian Dalam Pengajaran Bahasa Asing. Malang: P3T IKIP Malang

Djamarah dan Syaiful Bahri. 1999. Psikologi Belajar. Yogyakarta: Rineka Cipta

Government of Indonesia. 2003. Undang-Undang No. 20 Tahun 2003 tentang Sistem Pendidikan Nasional. Sekretariat Kabinet. Jakarta.

Hamalik Oemar. 2001. Proses Belajar Mengajar. Bandung: Bumi Aksara.

Jihad, A. dan Abdul Haris. 2012. Evaluasi Pembelajaran. Yogyakarta: Multi Presindo.

L.R. Gay \& Peter Airasian. 2000. Educational Research. USA: Prentice Hall.

Ngalim, Purwanto. 2004. Psikologi Pendidikan. Bandung: Rosda Karya.

Rusman. 2014. Model model Pembelajaran: Mengembangkan Profesionalisme Guru. Jakarta: PT Raja Grafindo Persada.

Saifudin Azwar. 1996. Pengantar Psikologi Intelegensi. Jogyakarta: Pustaka Pelajar.

Siswanto, Bejo. 2001. Manajemen Tenaga Kerja Indonesia. Jakarta: Bumi Aksara.

Slameto. 2013. Belajar dan Faktor-faktor yang Mempengaruhinya. Jakarta: Rineka Cipta. 
Sudjana. 2009. Metode Statistika. Bandung: Tarsito.

Sugiyono. 2006. Statistika Untuk Penelitian. Bandung: Alphabeta.

Sukardi. 2003. Metodologi Penelitian Pendidikan. Jakarta: Bumi Aksara.

Susanto, Ahmad. 2014. Teori Belajar dan Pembelajaran di Sekolah Dasar. Jakarta: Kencana.

Suprijono, Agus. 2013. Cooperative Learning. Surabaya: Pustaka Belajar.

Winardi. 2002. Motivasi dan Pemotivasian dalam Manajemen.Jakarta: PT. Raja Grafindo Persada.

Dwi, Eva, Muhsi and Fahrur Rozi. 2019. "Pengaruh Lingkungan Keluarga, Disiplin Belajar, Kompetensi Sosial Guru, dan Kesiapan Belajar terhadap Motivasi Belajar. Economic Education Analysis Journal. 8 - (1).

Fadilah, Siti Nur, Tedy Rusman and Nurdin. 2017. "Pengaruh Konsep Diri, Disiplin dan Minat terhadap Hasil Belajar melalui Motivasi Belajar”. Jurnal Edukasi Ekobis. 5 - (2).

Fitriwati, Dewi. 2018. "The Effect of Motivation on the Learning Achievement". Indonesian Journal of Integrated English Language Teaching (IJIELT). 4 (2).

Hidayati, Yuli. 2012. "Pengaruh Cara Belajar Terhadap Prestasi Belajar Siswa Kelas XII Jurusan Pemasaran Pada Mata Diklat Melaksanakan Proses Administrasi Transaksi Di SMK Taman Siswa Sumpiuh Tahun Pelajaran 2011/2012“. Oikonomia. 2 - (1).

Marpaung, Junierissa. 2015. "Pengaruh Gaya Belajar Terhadap Prestasi Belajar Siswa”. Jurnal Kopasta.2 - (2): 13 -17.

Mulyany, Parastining. 2013. "Pengaruh Keterampilan Mengajar Guru, Disiplin Belajar dan Sikap Siswa terhadap Motivasi Belajar Mata Diklat Bekerjasama dengan Kolega dan Pelanggan pada Siswa Kelas X Program Keahlian administrasi Perkantoran di SMK PL Tarcisius 1 Semarang”. Economic Education Analysis Journal. 2 - (3).

Nurmiati. 2017. "Hubungan Antara Cara Belajar dan Motivasi Belajar Siswa Dengan Hasil Belajar Biologi Siswa SMA di Kota Makassar”. Jurnal Saintifik. 3 - (1): $91-97$.

Prasetya, Eska. 2016. "The Effect of Students' Perception on School Environment and Self-Discipline Towards Their Achievement in Learning English: A Survey at A Private Vocational School in Bogor ". University of Bogor. 
Putri, Selvia, Tedy Rusman, and Rahma Dianti. 2019. "Pengaruh Cara Mengajar Guru, Cara Belajar, dan Perhatian Orang Tua melalui Motivasi Belajar terhadap Hasil Belajar IPS Terpadu”. Jurnal Edukasi Ekobis. 7 - (3).

Rahayu, Fitri. 2019. "Pengaruh Konsep Diri Dan Disiplin Belajar terhadap Motivasi Belajar Peserta Didik Di Sekolah Menengah Pertama Negeri 4 Palu Pada Mata Pelajaran Pendidikan Agama Islam”. Jurnal Peadagogia. 8 - (2).

Rizki Dwi, I Komang, and Tedy Rusman. 2014. "Pengaruh Persepsi Pemanfaatan Fasilitas dan Disiplin Melalui Motivasi terhadap Hasil Belajar Ekonomi”. Jurnal Edukasi Ekobis. 2 - (6).

Silvia Veri et al. 2019. "The Effect of Learning Discipline On Learning Achievement of Class X Students in Vocational High School 5 Padang”. International Journal of Educational Dynamics. 2 - (1).

Sutoro, Moh. 2018. "The Effect of Stress and Discipline on Employee Achievement in The Bank of Danamon South Tangerang”. Scientific Journal of Reflection. 1 - (2).

Syahrudin and Ricardo Latuheru. 2019. "The Effect of the Strength of Extremity and Motivation on Forward Roll of Achievement Learning". Journal of Physical Education Health and Sport. 6 - (1).

Tiara Ernita, Fatimah, and Rabiatul Adawiah. 2016. "Hubungan Cara Belajar Dengan Prestasi Belajar Siswa Dalam Mata Pelajaran PKN Pada Siswa Kelas X SMA Negeri 1 Banjarmasin”. Jurnal Pendidikan Kewarganegaraa. 6 $-(11)$.

Wijaya, Yustika, Yon Rizal, and Nurdin. 2019. "Pengaruh Efikasi Diri, Kreativitas, Cara Belajar terhadap Kemandirian melalui Motivasi Belajar”. Jurnal edukasi Ekobis. 7 - (2).

Yusriani, Siti. 2019. "Effect of Discipline Study, Family Environment, and Motivation Learning on Student Achievement". University of Jakarta. 